\title{
Diagnestics of Circular Sawblade Vibration by Displacement Sensors
}

\section{Dijagnostika vibracija lista kružne pile uz pomoć davača pomaka}

\author{
Original scientific paper • Izvorni znanstveni rad \\ Received-prispjelo: 30. 9. 2011. \\ Accepted-prihvaćeno: 16. 5. 2012. \\ UDK: $630 * 822 ; 674.053$ \\ doi:10.5552/drind.2012.1130
}

\begin{abstract}
The paper deals with problems of the circular sawblade vibration. In the introductory part, theoretical bases are summarized to determine the form of vibrations and critical and resonant rotational frequency. A diagnostic method is proposed for the direct measurement of amplitudes of a circular sawblade by displacement sensors with the subsequent Fast Fourier Transform (FFT) analysis. This method with the spectral analysis of a signal in the time area makes possible to determine the size and shape of vibration of a circular sawblade with respect to usability/applicability under operational conditions. Unlike standard methods, when the sawblade is excited by external sources, natural vibrations are used such as disk deformations and the dynamic unbalance of a circular sawblade, effects of chucking/gripping and machine vibration and, last but not least, the disk and sawn wood interaction.
\end{abstract}

Keywords: circular sawblade, critical rotational speed, resonant rotational speed, vibration, Fast Fourier Transform analysis

SAŽETAK • U radu se obrađuje problem vibracija lista kružne pile. U uvodnom dijelu daju se teorijske osnove za određivanje oblika vibracija te kritične i rezonantne frekvencije vrtnje. Predložena je dijagnostička metoda za neposredno mjerenje amplitude vibracija lista kružne pile uz pomoć davača pomaka i nakon toga uz pomoć Fast Fourierove (FFT) analize dobivenih podataka. Ta metoda sa spektarskom analizom realnog signala omogućuje određivanje veličine $i$ oblika vibracija lista kružne pile uzimajući u obzir uporabljivost/primjenjivost metode $u$ radnim uvjetima. Nasuprot standardnoj metodi, koja podrazumijeva pobudu lista pile na vibriranje vanjskim izvorima, u prezentiranoj se metodi iskorištavaju prirodni izvori pobude kao što su deformacija diska pile i dinamička neizbalansiranost, utjecaj vibracija stroja te interakcije lista kružne pile i obratka.

Ključne riječi: list kružne pile, kritična brzina vrtnje, rezonantna brzina vrtnje, vibracije, Fast Foruierova analiza

\section{INTRODUCTION}

\section{UVOD}

Today circular sawblades for cutting wood-based materials are rather complicated tools equipped with various construction adjustments. The construction adjustments and arrangements are particularly aimed at eliminating the negative effects of circular sawblade vibrations on the quality of cutting but also at improving hygienic conditions in the workplace from the point of view of noise and dust. In the past, static and dynamic vibrations of the circular sawblade disk were subject to extensive research and described rather comprehensively. Vibrations and a zone where resonant

\footnotetext{
${ }^{1}$ Authors are assistant, assistant professor and assistants at Faculty of Forestry and Wood Technology, Mendel University, Brno, Czech Republic.

${ }^{1}$ Autori su, redom, asistent, docent, asistent i asistent Fakulteta šumarstva i drvne tehnologije Mendelova sveučilišta, Brno, Republika Češka.
} 

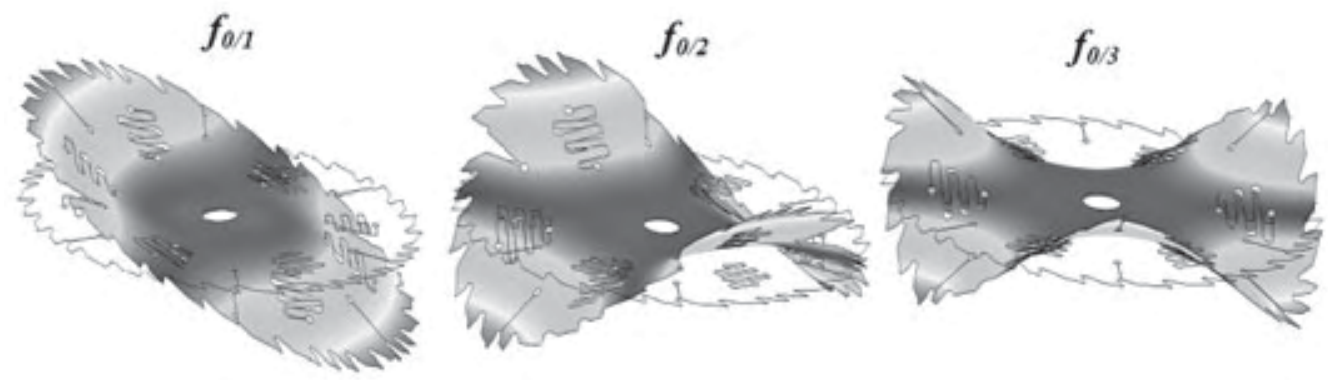

Figure 1 Central asymmetrical vibrations Slika 1. Središnje asimetrične vibracije

and critical rotational frequency occur affect substantially the cutting parameters.

In consequence of its disk form, the circular sawblade can have an infinite number of eigenfrequencies, which are characterized by a certain form of vibrations. There are centrally symmetric vibrations with nodal circles $c=0\left(f_{0}\right)$ and asymmetrical vibrations according to nodal diameters $k=1,2,3$ to $n\left(f_{0 / 1}, f_{0 / 2}, f_{0 / 3}\right.$, $\left.f_{0 / n}\right)$, see Fig. 1. In practice, the determination of the static frequency of the circular sawblade vibration is frequently dealt with experimentally. The creation of Chladni patterns is a diagnostic signal (Prokeš, 1978).

The form of vibrations and relevant eigenfrequencies of vibrations of a non-rotating disk can also be obtained by the Finite Element Method (FEM), (Kopecký et al, 2011), Fig. 1.

For the deflection $w$ of the disk in point $P$ on radius $r$ and at the angle of turning $\varphi$ a term (1) is given in literature (Nishio and Marui, 1996).

$$
w=w(r, \varphi, t)=N(r, \varphi) \cdot \sin k \varphi \cdot \cos 2 \pi \cdot f_{\mathrm{st}} \cdot t
$$

where:

$w=w(r, \varphi, t)$ - circular sawblade disk deflection at vibrations expressed in a polar coordinate system $(r, \varphi)$ in time $t$ / otklon lista pile pri vibriranju definiran u polarnom koordinatnom sustavu $(r, \varphi)$ u vremenu $t, \mathrm{~mm}$ $w_{O}$ - deflection of point $O /$ otklon točke $O$

$N(r, \varphi)$ - form function, which expresses the deflection of point $O$ in a polar coordinate system / funkcija oblika koja definira otklon točke O u polarnome koordinatnom sustavu

$f_{\text {st }}$ - frequency of eigenvibrations of a standing disk / vlastita frekvencija mirujućeg lista pile

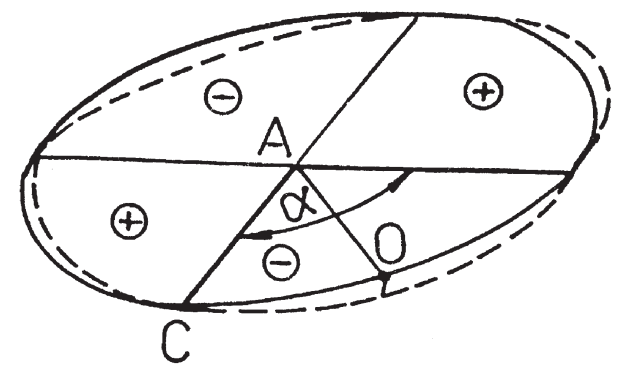

If the disk rotates with frequency $f_{n}$, the following equation can be used for the angle of turning

$$
\varphi=2 \cdot \pi \cdot f_{n} \cdot t
$$

By substitution into equation (1) and through an adaptation by means of the product of trigonometric functions $\sin \alpha \cdot \cos \beta$, the equation (1) can be transcribed into relation (3)

$$
\begin{aligned}
w(r, \varphi, t)= & \frac{f(r)}{2} \cdot \sin 2 \pi \cdot\left(f_{\mathrm{st}}+k \cdot f_{n}\right) \cdot t-\frac{f(r)}{2} . \\
& \cdot \sin 2 \pi \cdot\left(f_{\mathrm{st}}-k \cdot f_{n}\right) \cdot t
\end{aligned}
$$

The first element of the equation (3) represents a wave with the rotational speed of $60 \cdot f_{\mathrm{st}} / k\left(\mathrm{~min}^{-1}\right)$ progressing forwards, i.e. in the direction of rotation of the circular sawblade. The second element of the equation (3) represents a wave with the rotational speed of $60 \cdot f_{\mathrm{st}} / k\left(\mathrm{~min}^{-1}\right)$ progressing backwards, i.e. counter the rotation of the circular sawblade.

During research/development activities, an experimental method is often used (Siklienka and Svoreň, 1997). The determination of resonant and critical rotational frequency then results from the theory of vibration of a rotating circular sawblade. The dynamic frequency of vibration of a rotating circular sawblade $f_{\mathrm{d}}$ is quadratically affected by rotational frequency $f_{\mathrm{n}}$ (Stakhiev, 1989, 2003).

$$
f_{\mathrm{d}}=\sqrt{{f_{\mathrm{st}}}^{2}+\lambda \cdot f_{\mathrm{n}}{ }^{2}}
$$

or

$$
f_{\mathrm{d}}=f_{\mathrm{z}}+k \cdot f_{\mathrm{n}}
$$

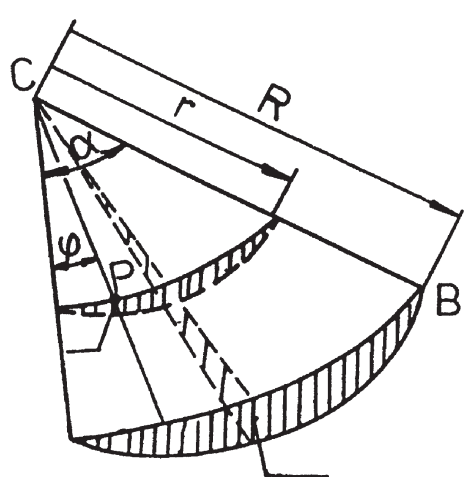

Figure 2 The sawblade disc deformation

Slika 2. Deformacije diska kružne pile 
where:

$f_{\text {st }}$ - eigenfrequency of vibrations of a non-rotating circular sawblade / vlastita frekvencija mirujućeg lista pile, $\mathrm{Hz}$

$k$ - number of nodal diameters $(k=1,2,3,4,5, \ldots) /$ broj čvornih promjera

$f_{\mathrm{z}}$ - frequency of backwards progressing wave / frekvencija natrag putujećeg vala

$\lambda$ - coefficient of centrifugal force / koeficijent centrifugalne sile

An important output of the experiment consists in the coefficient of centrifugal force $\lambda$, which is subsequently calculated from relations (4) and (5) on the basis of measured frequencies $f_{\mathrm{st}}, f_{\mathrm{z}}$ and the circular sawblade rotational frequency $f_{\mathrm{n}}$. Then, by substitution into known relations (Siklienka and Svoreň, 1997), resonant (6) and critical (7) rotational frequency of a circular sawblade can be determined expressed in $\mathrm{min}^{-1}$.

where:

$$
n_{\mathrm{r}}=\frac{60 \cdot f_{\mathrm{st}}}{\sqrt{(k+Z)^{2}-\lambda}}
$$

$Z$ - higher harmonic

$$
n_{\mathrm{k}}=\frac{60 \cdot f_{\mathrm{st}}}{\sqrt{k^{2}-\lambda}}
$$

\section{MATERIAL AND METHODS 2. MATERIJAL I METODE}

The subject of tests was a standard circular sawblade Pilana 400 x 4.4/3.2 x 30, 72 TFZL for large-area trimming to size. The proposed method consists in the position of sensors perpendicular to the circular sawblade area with a phase shift of $90^{\circ}$. Changing air gaps between sensors and the circular sawblade are recorded as the amplitude of vibration in two levels perpendicular to each other. The measurement was implemented on an experimental apparatus (see Fig. 3).

Unfortunately, the original setting of sensors with the phase shift of $180^{\circ}$ did not bring definite results to determine the form of vibrations, particularly for the first and the second nodal diameter. At the present layout, which can be changed any time thanks to magnetic stands, sensors are placed at the sawblade rim at a level below teeth; teeth being shifted with one another by $90^{\circ}$.

Signals from sensors were transferred by a Spider 8 data logger to a PC and further processed using the Conmes Spider program. The course of vibration amplitudes on the disk rim was scanned with the sampling frequency of $300 \mathrm{~Hz}$. Sampling frequency higher than $1200 \mathrm{~Hz}$ (weighted average-filtered frequency of $150 \mathrm{~Hz}$ ) was used for reliable registration of unstable state. FFT analysis was done in program Skylab.

\section{RESULTS AND DISCUSSION} 3. REZULTATI I RASPRAVA

The aim of the newly designed method for measuring vibrations of the disk by displacement sensors is to obtain more detailed information on shapes of vibration without using rather complicated experimental stands. The possibility of diagnostics of a problematic circular sawblade directly on a saw under operational conditions is considered to be an advantage.

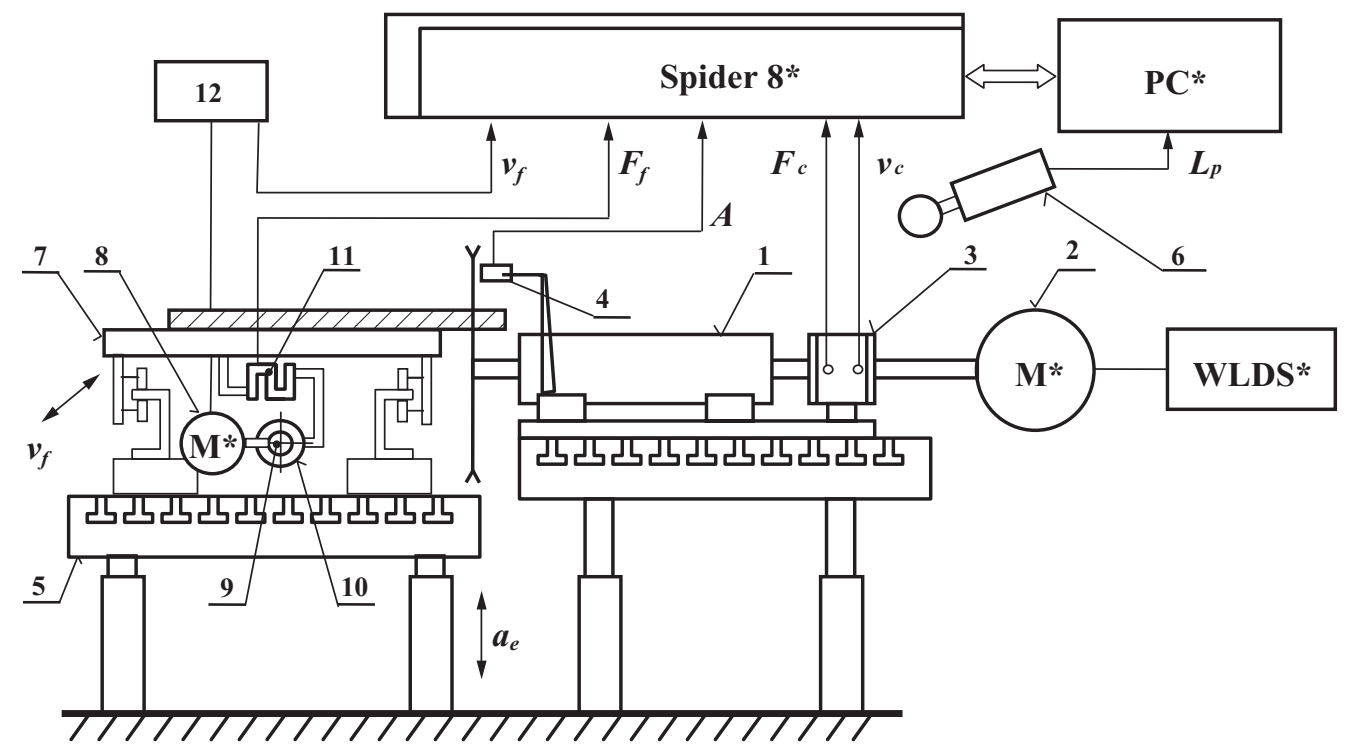

1 - spindle / vreteno, 2 - electric motor with adjustable speed (Ward Leonard Drive System) / elektromotor s mogućnošću promjene vrtnje, 3 - torque transducer with a speed sensor (HBM T34 FN) / davač momenta sa senzorom brzine vrtnje, 4 - contactless current displacement transducer (EPRO PR6423/000-001) / beskontaktni davač pomaka, 5 - grate table / radni stol, 6 - sound level meter / zvukomjer, 7 - feeding carriage / posmični uređaj, 8 - electric motor for the carriage feed / elektromotor za posmak, 9 - ball screw / kuglični vijak, 10 - nut / matica, 11 - feeding force sensor $F_{f} /$ senzor posmične snage, 12 - frequency converter / pretvarač frekvencije

Figure 3 A scheme of the experimental stand

Slika 3. Shema provedbe eksperimenta 


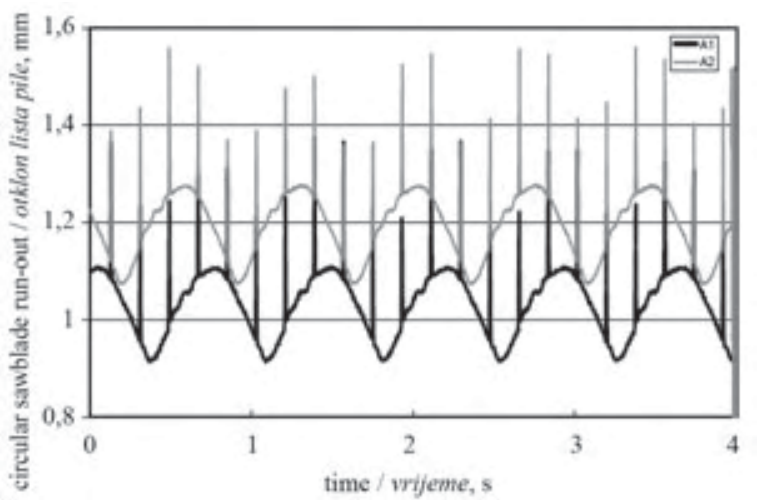

Figure 4 Running a circular sawblade at $83 \mathrm{~min}^{-1}$

Slika 4. Vrtnja lista kružne pile frekvencijom $83 \mathrm{~min}^{-1}$

The essential part of diagnostics of the disk vibration is the determination of the disk deformation and run-out. The results show whether the circular sawblade may be used for the process of cutting (in practice, max. allowable amplitude of run-out is 0.1 $\mathrm{mm})$. At low rotational speed $\left(83 \mathrm{~min}^{-1}\right)$, when the disk and spindle vibration are not affected by heat stress and tension as a consequence of centrifugal forces, both sensors (A1 and A2) measured max. amplitude of $0.08 \mathrm{~mm}$, which can be considered to be a satisfactory value (see Fig. 4). The four radial compensatory grooves create the peaks.

When determening resonant and critical rotational frequency of a circular sawblade under operational conditions, it is first necessary to examine eigenfrequencies of vibration $f_{\text {st }}$ of a standing circular sawblade $f_{\mathrm{n}}=0$. An impulse impact method (Orlowski et al, 2007) ranks among most suitable methods.

After a subsequent Fast Fourier Transform (FFT), it is possible to obtain natural frequencies of the sawblade disk vibration in particular nodal diameters $(k=1,2$, $3, \ldots)$. If we compare eigenfrequencies of the tested disk obtained previously according to a conventional method using Chladni patterns (Kopecký, 2007), a very good consistency of analysed data can be noted. The eigenfrequencies of vibration were $f_{\text {st }}=89 \mathrm{~Hz}$ for $k=1, f_{\text {st }}=147$ $\mathrm{Hz}$ for $k=2$ and $f_{\mathrm{st}}=261.9 \mathrm{~Hz}$ for $k=3$ (see Fig. 5).
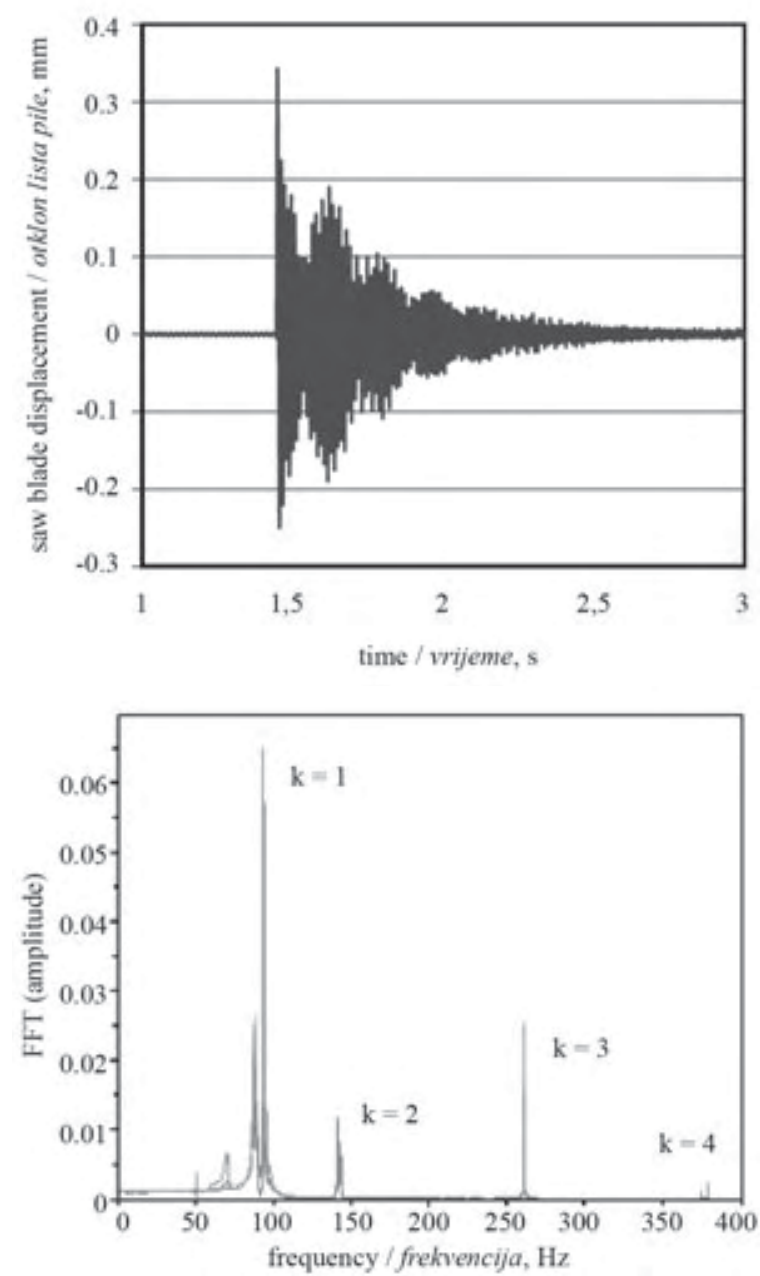

Figure 5 Impulse impact method and eigenfrequencies of the circular sawblade vibration by FFT

Slika 5. Metoda pobude lista pile i određivanje vlastitih frekvencija lista FFT analizom

With direct measurement of vibrations by displacement sensors, zones of increased vibrations and zones with low amplitude of vibrations were looked for in the next stage of the experiment (see Fig. 6). Based on the diagram, the applicable running speed ranging

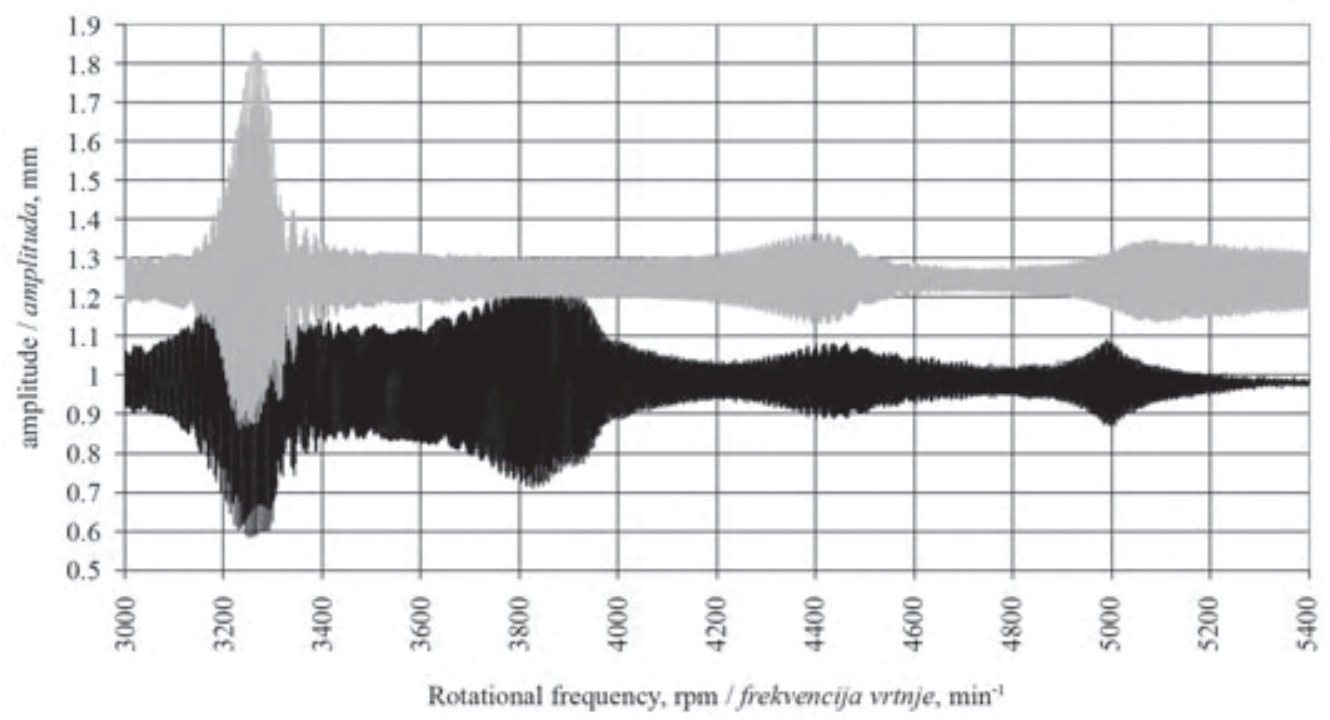

Figure 6 Changes of vibration amplitudes on the disk rim with the sensors A1, A2 shifted with one another by $90^{\circ}$ Slika 6. Promjene amplitude vibracija na rubu diska kružne pile određene davačima pomaka A1 i A2 pomaknutima za $90^{\circ}$ 


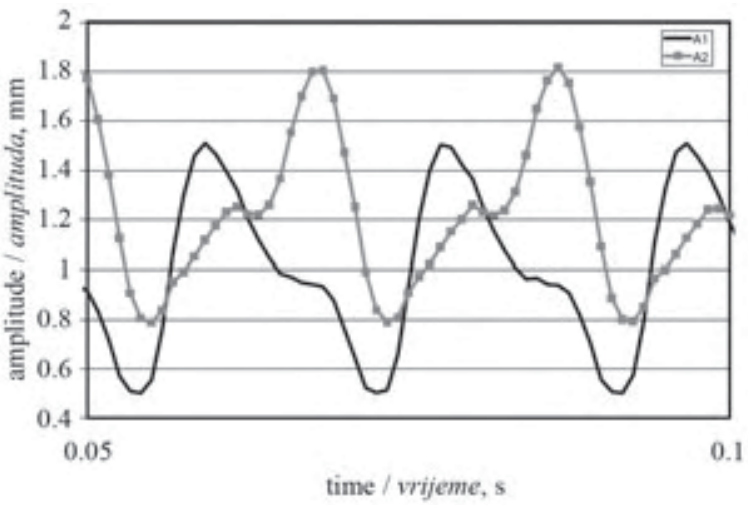

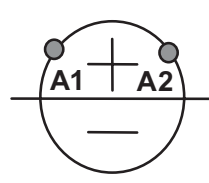

$k=1$

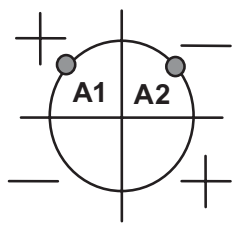

$k=2$

Figure 7 Record of vibration amplitudes at $3320 \mathrm{~min}^{-1}(55 \mathrm{~Hz})$ sensed by sensors A1 and A2 with a phase shift of $90^{\circ}$ Slika 7. Amplitude vibracija lista pile pri frekvenciji vrtnje $3320 \mathrm{~min}^{-1}(55 \mathrm{~Hz})$ zabilježene davačima pomaka A1 i A2 pomaknutima za $90^{\circ}$
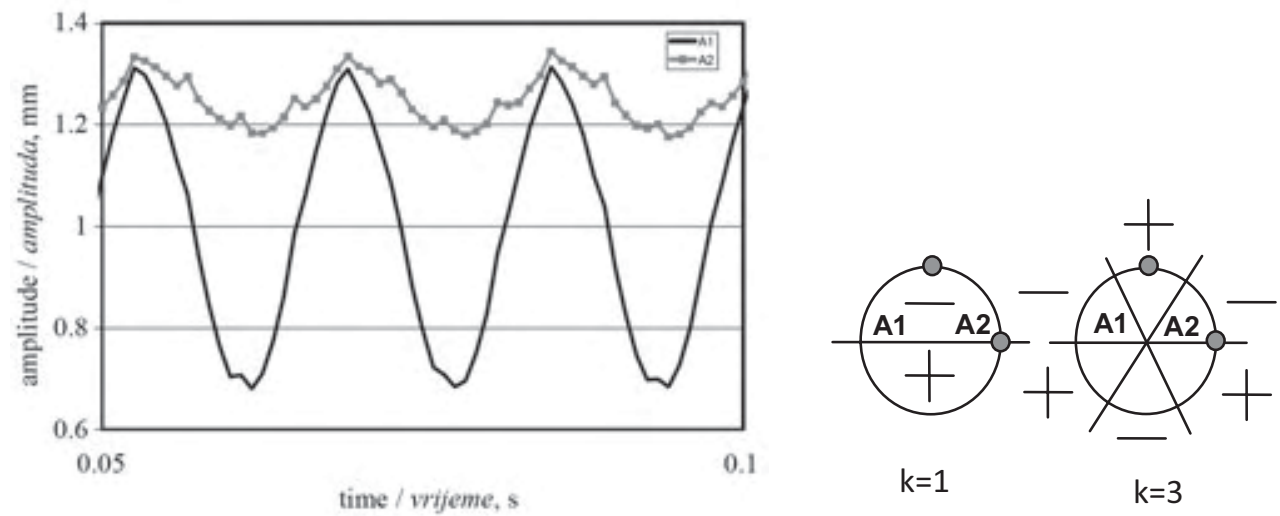

Figure 8 Record of vibration amplitudes at $3720 \mathrm{~min}^{-1}(62 \mathrm{~Hz})$ sensed by sensors A1 and A2 with a phase shift of $90^{\circ}$ Slika 8. Amplitude vibracija lista pile pri frekvenciji vrtnje $3720 \mathrm{~min}^{-1}(62 \mathrm{~Hz})$ zabilježene davačima pomaka A1 i A2 pomaknutima za $90^{\circ}$

between 4100 and $4200 \mathrm{~min}^{-1}$ can also be estimated without increasing vibration. Thus, it is evident that owing to the progressive wave motion, amplitudes of vibrations are roughly identical or several-fold different at certain rotational frequency.

It is known that at approaching the frequency of the disk vibration to the frequency of the disk rotation, unstable states occur. In unstable zones, more detailed measurements were carried out with the sampling frequency higher than $1200 \mathrm{~Hz}$ for reliable registration of the process. As an example, the records of vibration are given at 3320 and $3720 \mathrm{~min}^{-1}$ (see Fig. 7 and 8).

At $3320 \mathrm{~min}^{-1}$, dominant vibrations of the first or the second nodal diameter can be expected. The curves of vibration amplitudes are approximately identical but turned up. The backward progressive wave is the cause of this effect (see Fig. 7).

At $3720 \mathrm{~min}^{-1}$, dominant vibrations of the first or the third nodal diameter can be expected. The curves of vibration amplitudes are in phase. Sensor $A 2$ recorded small amplitudes, whose dimension failed to exceed the run-out. This point can be indicated as the balance point. Sensor $A 1$ recorded high amplitudes in accordance with max deflection ( + or -) of the disk.

FFT of a measured signal proved the hypothesis that at $3720 \mathrm{~min}^{-1}$ it referred to dominance of the first nodal diameter. After a more detailed analysis, the frequency of backwards progressive wave is evident at the first nodal diameter $f_{\mathrm{z}}=49 \mathrm{~Hz}$ (see Fig. 9). In the amplitude-frequency spectrum, speed frequencies $f_{\mathrm{n}}=$ $62 \mathrm{~Hz}$ and its other harmonics also occur. FFT analysis was done from record of vibration amplitudes in program Skylab.

Based on the analysed data, rather good consistency is found of the determined frequency of a backward progressive wave with previous results obtained according to conventional methods (Kopecký, 2007), see Tab. 1 .

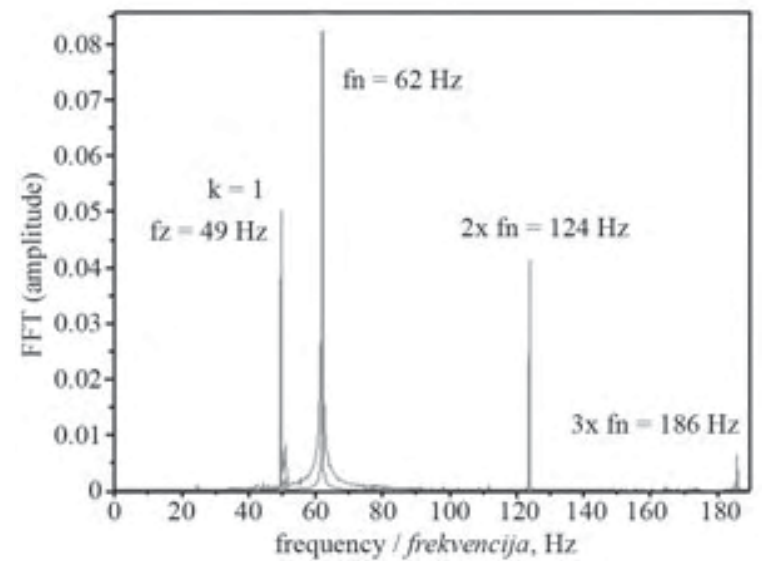

Figure 9 Amplitude-frequency spectrum of disk vibration at $3720 \mathrm{~min}^{-1}(62 \mathrm{~Hz})$

Slika 9. Spektar amplitude-frekvencija za vibracije lista pile pri frekvenciji vrtnje $3720 \mathrm{~min}^{-1}(62 \mathrm{~Hz})$ 
Table 1 Results of conventional method

Tablica 1. Rezultati konvencionalne metode

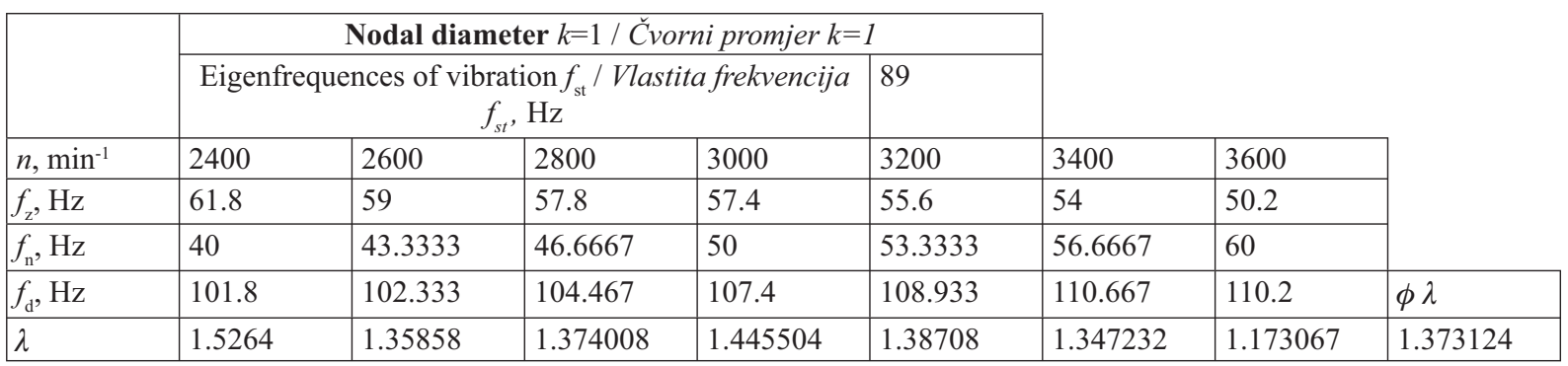

By substitution of the backward progressive wave $f_{z}=49 \mathrm{~Hz}$ into relation (5) the dynamic eigenfrequency of the rotating disk vibration $f_{\mathrm{d}}$ can be calculated and by a simple modification of the relation (4), the coefficient of centrifugal force $\lambda$ for the given nodal diameter can be determined. The coefficient of centrifugal force is then an important parameter for the calculation of resonance or critical rotational frequency (see relations (6) and (7). In the analysed case, resonant frequency $(Z=1)$ of the first nodal diameter $n_{\mathrm{r} 1}(k l)$ is achieved at $3160 \mathrm{~min}^{-1}$. A similar procedure can be applied for the second nodal diameter $k=2$ and the first critical rotational speed can be determined.

\section{CONCLUSIONS}

\section{ZAKLJUČCl}

The proposed method of the direct monitoring the circular sawblade vibrations by two displacement sensors provides more detailed information on unstable states of the circular sawblade, which are caused by natural processes at its rotation. Determination of the frequency of a backward progressive wave $f_{\mathrm{z}}$ with the possibility of an approximate determination of the coefficient of centrifugal force $\lambda$ and calculation of resonance and critical rotational frequency is valuable information obtained from the amplitude-frequency analysis.

The method is, however, sensitive to the excitation of the disk vibration, e.g. from the disk dynamic unbalance, effects of fastening, changes in the inertia of drive and, last but not least, the machine vibration. An indisputable advantage consists in its application as the operational diagnostics of circular saws not requiring any disassembly. Thus, due to the easy mobility of sensors, it is possible to diagnose not only the particular circular sawblade but also a spindle, flanges or bearing clearance and to assess the effects of inaccuracies of these machine parts on the whole result of a cutting process.

\section{Acknowledgement - Zahvala}

This paper was prepared in connection with a partial project within the CR MSM 6215648902 Rese- arch Plan and IGA PROJEKTS 1/2010, 5/2010 LDF MENDELU Brno. The author thanks for a financial support to deal with the project.

\section{REFERENCES}

5. LITERATURA

1. Kopecký, Z., 2007: Vybrané aspekty vysokorychlostního obrábění dřeva. MZLU Brno, (2007), 303 pp. [Habilitation thesis]

2. Kopecký, Z.; Veselý, P.; Rousek, M.; Karolczak, P., 2011: Wplyw konstrukcji pil tarczowych na poziom generowanego przez nie nateźenia dźwieku. In: Obróbka skrawaniem - Nauka a przemysl. No. 5. Politechnika Opolska: Wydawnictwo Sutoris Wroclaw, 2011. pp. 395-400.

3. Nishio, S.; Marui, E., 1996: Effects of Slots on the Lateral Vibration of Circular Saw Blade. Proccedings of the tenth Wood Machining Seminar, pp. 159-164.

4. Orlowski, K.; Sandak, J.; Tanaka, Ch., 2007: The critical rotational speed of circular saw: simple measurement method and its practical implementations. Journal of Wood Science 53: 388-393 http://dx.doi.org/10.1007/s10086-006-0873-5.

5. Prokeš, S., 1978: Obrábění dřeva a nových hmot ze dřeva. Praha, SNTL, 1978, 583 pp.

6. Siklienka, M.; Svoreň, J., 1997: Frekvencie vlastných tvarov kmitov pílových kotúčov při statickom kmitaní. TU Zvolen.

7. Stakhiev, Y. M., 1989: Rabotosposobnost' ploskich kruglych pil. Moskva: Lesnaja promyšlenost, 384 pp.

8. Stakhiev, Y. M., 2003: Research on circular saw disc problems: several of results. Holz als Roh- und Werkstoff 61: 13-22 http://dx.doi.org/10.1007/s00107-002-0353-6.

\section{Corresponding address:}

Assistant PŘEMYSL VESELÝ, Ph.D.

Faculty of Forestry and Wood Technology

Mendel University

Zemědělská 3

61300 Brno, CZECH REPUBLIC

e-mail: vesely@mendelu.cz 